\title{
Polyoxin D and Other Biopesticides Reduce Gummy Stem Blight But Not Anthracnose on Melon Seedlings
}

\author{
Anthony P. Keinath, Clemson University, Coastal Research and Education Center, Charleston, SC 29414-5329 \\ Accepted for publication 1 July 2016. Published 4 August 2016.
}

\section{ABSTRACT}

Keinath, A. P. 2016. Polyoxin D and other biopesticides reduce gummy stem blight but not anthracnose on melon seedlings. Plant Health Prog. 17:177-181.

Biopesticides may be useful to prevent fungal foliar diseases on cucurbit seedlings in greenhouses because of the short re-entry intervals, normally 4 h. Bacillus subtilis QST 713 (Serenade ASO), root extract of Reynoutria sachalinensis (Regalia), hydrogen dioxide (Oxidate), paraffinic oil (JMS Stylet Oil), polyoxin D (Oso), and 92\% edible fish oil $+5 \%$ sesame oil (Organocide) were evaluated against gummy stem blight on muskmelon seedlings and anthracnose on watermelon seedlings. Polyoxin D applied alone, B. subtilis QST 713 followed by polyoxin $\mathrm{D}$, and $R$. sachalinensis extract followed by $B$. subtilis QST 713 reduced the severity of gummy stem blight and were as effective as mancozeb. None of the biopesticides applied alone or sequentially were effective against anthracnose. Polyoxin D could be used to prevent outbreaks of gummy stem blight on watermelon and muskmelon seedlings grown for use as transplants.

\section{INTRODUCTION}

Gummy stem blight of cucurbits is caused by the fungus previously named Didymella bryoniae (Auersw.) Rehm, which recently was shown to be a complex of three morphologically identical, genetically distinct species: Stagonosporopsis citrulli M.T. Brewer \& J.E. Stewart; S. cucurbitacearum (Fr.) Aveskamp, Gruyter \& Verkley; and S. caricae (Sydow \& P. Sydow) Aveskamp (Stewart et al. 2015). Gummy stem blight can occur on watermelon (Citrullus lanatus (Thunb.) Matsum. \& Nakai var. lanatus) and muskmelon (Cucumis melo L.) seedlings grown for use as transplants and on greenhouse-grown cucumber ( $C$. sativus L.) and melon crops (Boughalleb et al. 2007; Brown et al. 1970; Cedeño et al. 2000; Crinò et al. 2007; Hendricks and Roberts 2015; Keinath 2009, 2011, 2012; Koike 1997; Latin 1993; Stevenson et al. 2004; van Steekelenburg 1983). Infected seedlings can be a source of inoculum for field crops (Boughalleb et al. 2007; Keinath 1996). Seeds contaminated with Stagonosporopsis spp. produce diseased seedlings, and the fungus spreads rapidly from these initial foci to surrounding seedlings (Brown et al. 1970; Keinath 1996, 2013; Lee et al. 1984). Airborne ascospores of Stagonosporopsis spp. produced on debris remaining from diseased, previous crops are an additional source of inoculum in greenhouses (van Steekelenburg 1983).

Anthracnose, caused by the fungus Colletotrichum orbiculare (Berk. \& Mont.) Arx, is another cucurbit seedling disease found in greenhouses. It was found on greenhouse-grown watermelon seedlings in Indiana and California in 1991 (Koike et al. 1991; Latin 1993). Cucumber seed contaminated with $C$. orbiculare produced cucumber seedlings with anthracnose symptoms (Horn and Wilson 1955); however, reports of transmission of Colletotrichum on cucurbit seed are less common than reports of

Corresponding author: A. P. Keinath. Email: tknth@clemson.edu.
Stagonosporopsis. When watermelon seed was inoculated with either pathogen, $67 \%$ of the cotyledons and embryos were infected by Stagonosporopsis, but $<2 \%$ were infected by $C$. orbiculare (Rankin 1954). Hybrid watermelon is susceptible to $C$. orbiculare race 2, whereas muskmelon is susceptible to races 1,2 , and 2B (Keinath 2015; Wasilwa et al. 1996). Anthracnose is the only disease mentioned in the USDA (2006) standards for grades of watermelon fruit; therefore, to maintain fruit quality it is critical to eliminate diseased seedlings as a source of inoculum.

Biopesticides, as defined by the U.S. Environmental Protection Agency, include microorganisms and their products and other biochemical substances "that have a nontoxic mode of action" (Leahy et al. 2014). Biopesticides would be very useful for managing gummy stem blight and anthracnose in greenhouse operations that produce melon transplants. The short re-entry intervals for biopesticides, generally $4 \mathrm{~h}$, make it easier to schedule applications around hand watering times and other tasks. Mancozeb and cyprodinil-fludioxonil are the only fungicides effective against gummy stem blight that are registered for greenhouse use on cucurbits, but re-entry intervals are 24 and 12 $\mathrm{h}$, respectively (Keinath 2013b). In addition, growers of organic transplants need effective biopesticides or synthetic substances allowed by the National Organic Program (NOP). Although applications of fixed copper and sulfur are allowed in organic agriculture, copper is ineffective against gummy stem blight (Keinath et al. 2000). In general, sulfur products are registered only against powdery mildew on cucurbits. Another advantage of using biopesticides in place of conventional fungicides is that they could prevent the occurrence of resistance to fungicides in Stagonosporopsis spp. Isolates of this pathogen resistant to quinone-outside-inhibitor fungicides, such as azoxystrobin, and to succinate-dehyrogenase-inhibitor fungicides, such as boscalid, have been found in commercial transplant production facilities in the southeastern United States (Hendricks and Roberts 2015; Keinath 2009, 2012; Stevenson et al. 2004).

A number of biopesticides are registered for use on cucurbits in the greenhouse and are marketed to control gummy stem blight 
and anthracnose. These biopesticides include potassium bicarbonate (Armicarb), Bacillus subtilis (Serenade ASO), root extract of Reynoutria sachalinensis (Regalia), hydrogen dioxide (Oxidate), and polyoxin D zinc salt (Oso). In addition, paraffinic oil (JMS Stylet Oil) may be used in the greenhouse on cucurbits against gummy stem blight. In a previous field experiment, polyoxin D reduced severity of gummy stem blight (Keinath et al. 2011). Potassium bicarbonate reduced severity of gummy stem blight in the greenhouse but not in the field (McGovern 1993; Ziv and Zitter 1992). Because paraffinic oil was effective in a previous greenhouse experiment, another biopesticide oil, a product of $92 \%$ edible fish oil $+5 \%$ sesame oil (Organocide), also was included in the present study (Ziv and Zitter 1992).

\section{SCREENING BIOPESTICIDES AGAINST GUMMY STEM BLIGHT}

The experimental design was a randomized complete block with four replications. Each replication was one pot with three seedlings of muskmelon 'Athena.' Seedlings with two true leaves were sprayed with the maximum-labeled rates of biopesticides dissolved or suspended in the equivalent of 100 gpa (Table 1). The following day, treated seedlings were inoculated by spraying with a suspension of $10^{6}$ conidia/ml of $S$. citrulli isolate W771. Inoculated seedlings were immediately placed in a humidity chamber at $100 \%$ relative humidity. Gummy stem blight incidence (percentage of plants with any symptoms) and severity (percentage leaf area diseased) were rated 3 days after inoculation. The experiment was done twice. Data were transformed with arcsine of the square root before analysis with SAS PROC GLM for mixed model analysis of variance (SAS 9.3, SAS Institute Inc., Cary, NC). Model fits were evaluated with

\begin{tabular}{|c|c|c|c|c|}
\hline \multicolumn{5}{|c|}{$\begin{array}{c}\text { TABLE } 1 \\
\begin{array}{c}\text { Efficacy of biopesticides against gummy stem blight } \\
\text { on muskmelon seedlings. }\end{array}\end{array}$} \\
\hline Treatment & Product & $\begin{array}{l}\text { Rate per } \\
100 \text { gal }\end{array}$ & $\begin{array}{l}\text { Incidence } \\
(\%)^{x}\end{array}$ & $\begin{array}{l}\text { Severity } \\
(\%)^{\mathrm{x}}\end{array}$ \\
\hline $\begin{array}{l}\text { Water (inoculated } \\
\text { control) }\end{array}$ & & NA & $100.0 \mathrm{a}$ & $21.5 \mathrm{a}$ \\
\hline Paraffinic oil $97 \%$ & $\begin{array}{l}\text { JMS Stylet } \\
\text { Oil }\end{array}$ & $6 \mathrm{qt}$ & $100.0 \mathrm{a}$ & $19.7 \mathrm{a}$ \\
\hline $\begin{array}{l}\text { Hydrogen dioxide } \\
27 \%\end{array}$ & Oxidate & $1 \mathrm{gal}$ & $99.4 \mathrm{ab}$ & $14.0 \mathrm{a}$ \\
\hline $\begin{array}{l}\text { Edible fish oil } 92 \%+ \\
\text { sesame oil } 5 \%\end{array}$ & Organocide & $2 \mathrm{gal}$ & $100.0 \mathrm{a}$ & $6.1 \mathrm{~b}$ \\
\hline $\begin{array}{l}\text { Bacillus subtilis } \\
\text { QST713 1.34\% }\end{array}$ & $\begin{array}{l}\text { Serenade } \\
\text { ASO }\end{array}$ & $6 \mathrm{qt}$ & $85.9 \mathrm{bc}$ & $2.7 \mathrm{bc}$ \\
\hline $\begin{array}{l}\text { Reynoutria } \\
\text { sachalinensis extract } \\
5 \%\end{array}$ & Regalia & $1 \mathrm{gal}$ & $73.0 \mathrm{c}$ & $2.7 \mathrm{bc}$ \\
\hline $\begin{array}{l}\text { Polyoxin D zinc salt } \\
5 \% \mathrm{SC}\end{array}$ & Oso & $14 \mathrm{fl} \mathrm{oz}$ & $23.3 \mathrm{~d}$ & $0.7 \mathrm{~cd}$ \\
\hline Mancozeb 75DG & $\begin{array}{l}\text { Manzate } \\
\text { Pro-Stick }\end{array}$ & $2-3 \mathrm{lb}^{\mathrm{y}}$ & $11.8 \mathrm{~d}$ & $0.1 \mathrm{~d}$ \\
\hline $\begin{array}{l}\text { Water (non-inoculated } \\
\text { control) }\end{array}$ & & NA & $0.0 \mathrm{e}$ & $0.0 \mathrm{~d}$ \\
\hline
\end{tabular}

${ }^{\mathrm{x}}$ Means were calculated from two experiments with four replications per experiment. Means within columns followed by the same letter are not significantly different, Waller-Duncan k-ratio t tests, $P=0.01$.

${ }^{y}$ Mancozeb was applied at $3 \mathrm{lb} / 100 \mathrm{gal}$ in the first trial and $2 \mathrm{lb} / 100 \mathrm{gal}$ in the second trial. plots of residuals. Data from the two trials (repetitions of the experiment) were combined for analysis, as there were no differences between the trials and no interactions between trial and treatment.

All nontreated, inoculated plants had a least one leaf spot of gummy stem blight (an incidence of 100\%) (Fig. 1) (Table 1). Biopesticides varied in their performance against gummy stem blight from completely ineffective to very effective (Table 1). Polyoxin D reduced the number of seedlings with symptoms (incidence) and limited the size of leaf spots (severity). It was the only product as effective as mancozeb, and it resulted in a significantly lower incidence than all other biopesticides. Severity on seedlings treated with mancozeb or polyoxin D did not differ from severity on the non-inoculated control seedlings, which were completely free of gummy stem blight. A reduction in incidence is important because Stagonosporopsis spp. can spread rapidly from infected seedlings to surrounding seedlings once spores are produced (Keinath 1996, 2011, 2013a). B. subtilis QST 713 and $R$. sachalinensis extract also reduced incidence compared to the nontreated control but not to the extent that polyoxin D did. Although B. subtilis QST 713 and $R$. sachalinensis extract reduced severity as well as Polyoxin D, severity with these two biopesticides was greater than on the non-inoculated seedlings. JMS Stylet Oil, Oxidate, and Organocide did not reduce incidence, and, of these three, only Organocide reduced severity.

Potassium bicarbonate $85 \%$ (Armicarb 100) was tested at 5 $\mathrm{lb} / 100 \mathrm{gal}$ in the first trial, but it caused phytotoxicity on all treated seedlings. Organocide also caused phytotoxicity on treated seedlings in the first trial but not in the second trial (data not shown). Because of the phytotoxicity observed, a separate experiment to test phytotoxicity was done. Seedlings were treated with biopesticides as described above, not inoculated, and left on the greenhouse bench. Seedlings were rated for severity of phytotoxicity at 1,3 , and 7 days after treatment. Phytotoxicity was observed with Armicarb applied at 5 and $2.5 \mathrm{lb} / 100$ gal but not with any other treatments.

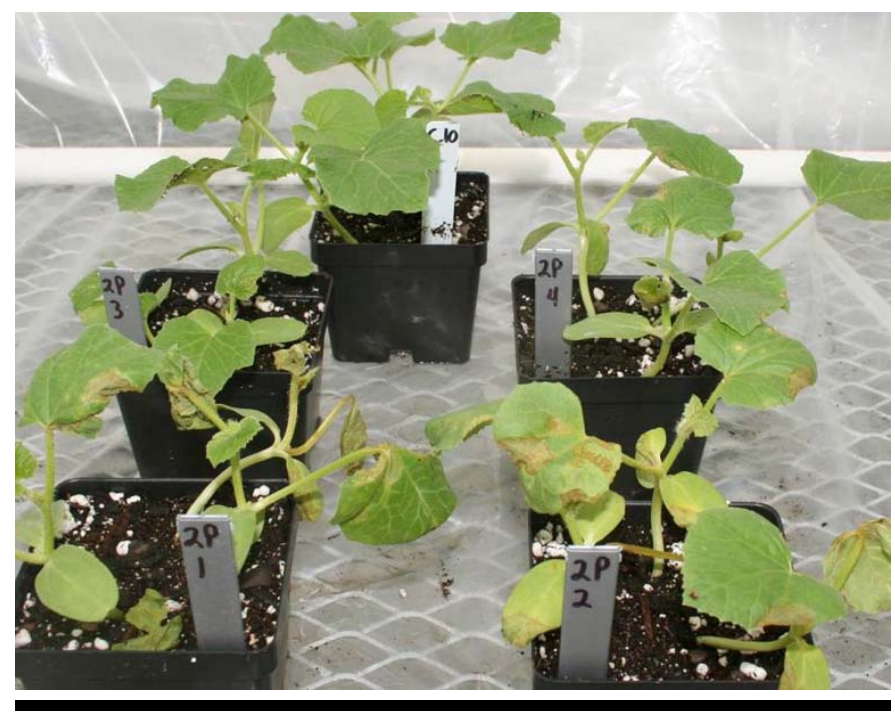

\section{FIGURE 1}

Symptoms of gummy stem blight on muskmelon seedlings 3 days after inoculation. The seedlings in the four pots in the foreground were inoculated with Stagonosporopsis sp., and the seedlings in the rear pot were sprayed with water. 


\section{COMBINING BIOPESTICIDES AGAINST GUMMY STEM BLIGHT}

R. sachalinensis extract, B. subtilis QST 713, and Polyoxin D were applied alone or in sequence with each other to determine if applications of two or three biopesticides were more effective than single biopesticides (Table 2). The sequential experiment used the same basic procedures as the screening experiment. In order to standardize comparisons among treatments, $R$. sachalinensis extract, B. subtilis QST 713, and Polyoxin D were applied 4, 2, and 0 days before inoculation, respectively, in the first trial, and 4, 2, and 1 day before inoculation in the second trial in all sequences (Table 2). For the final application in the first trial, plants were treated in the morning and inoculated in the afternoon to ensure that leaves had dried. Treated seedlings were inoculated with S. citrulli isolate W732 and incubated, and severity was rated and analyzed, as described previously. Data from the two trials were combined for analysis, as there were no interactions between trial and treatment.

Gummy stem blight was somewhat more severe in this experiment than in the screening experiment, as mean severity on inoculated control seedlings was $37 \%$ compared to $21 \%$, respectively. Using a different isolate of Stagonosporopsis may have increased severity. The more severe disease may partially explain why $R$. sachalinensis extract and B. subtilis QST 713 applied alone were not effective in this experiment (compared to the water control), whereas they were in the previous experiment (Table 2). Disease was less severe with all other biopesticide treatments and with mancozeb than with the water control $(P=$

\begin{tabular}{|c|c|c|c|}
\hline \multicolumn{4}{|c|}{$\begin{array}{l}\text { TABLE } 2 \\
\text { Efficacy of three biopesticides applied alone or } \\
\text { in combination against gummy stem blight on } \\
\text { muskmelon seedlings. }{ }^{x}\end{array}$} \\
\hline Treatment 1 & Treatment 2 & Treatment 3 & $\begin{array}{c}\text { Severity } \\
(\%)^{y}\end{array}$ \\
\hline $\begin{array}{l}\text { Water (inoculated } \\
\text { control) }\end{array}$ & Water & Water & $37.0 \mathrm{a}$ \\
\hline $\begin{array}{l}\text { Reynoutria } \\
\text { sachalinensis } \\
\text { extract } 5 \%\end{array}$ & Water & Water & $32.6 \mathrm{a}$ \\
\hline Water & $\begin{array}{l}\text { Bacillus subtilis } \\
\text { QST713 1.34\% }\end{array}$ & Water & $22.6 \mathrm{ab}$ \\
\hline $\begin{array}{l}\text { Reynoutria } \\
\text { sachalinensis } \\
\text { extract } 5 \%\end{array}$ & Water & $\begin{array}{l}\text { Polyoxin D } \\
\text { zinc salt } 5 \%\end{array}$ & $14.7 \mathrm{bc}$ \\
\hline $\begin{array}{l}\text { Reynoutria } \\
\text { sachalinensis } \\
\text { extract } 5 \%\end{array}$ & $\begin{array}{l}\text { Bacillus subtilis } \\
\text { QST713 1.34\% }\end{array}$ & $\begin{array}{l}\text { Polyoxin D } \\
\text { zinc salt } 5 \%\end{array}$ & $13.1 \mathrm{bcd}$ \\
\hline $\begin{array}{l}\text { Reynoutria } \\
\text { sachalinensis } \\
\text { extract } 5 \%\end{array}$ & $\begin{array}{l}\text { Bacillus subtilis } \\
\text { QST713 } 1.34 \%\end{array}$ & Water & 10.4 bcde \\
\hline Water & $\begin{array}{l}\text { Bacillus subtilis } \\
\text { QST713 1.34\% }\end{array}$ & $\begin{array}{l}\text { Polyoxin D } \\
\text { zinc salt } 5 \%\end{array}$ & $4.7 \mathrm{cde}$ \\
\hline Water & Water & $\begin{array}{l}\text { Polyoxin D } \\
\text { zinc salt } 5 \%\end{array}$ & $2.8 \mathrm{def}$ \\
\hline Water & Water & $\begin{array}{l}\text { Mancozeb } \\
75 \%\end{array}$ & 1.9 ef \\
\hline $\begin{array}{l}\text { Water (non- } \\
\text { inoculated control) }\end{array}$ & Water & Water & $0.0 \mathrm{f}$ \\
\hline
\end{tabular}

${ }^{\mathrm{x}}$ Biopesticides were applied at the rates given in Table 1.

${ }^{y}$ Means were calculated from two experiments with four replications per experiment. Means within columns followed by the same letter are not significantly different, Waller-Duncan k-ratio t tests, $P=0.01$.
0.01). No disease developed in the noninoculated control. The level of disease that developed on seedlings treated with mancozeb or Polyoxin D $(\leq 3 \%)$ was not significantly greater than on the noninoculated control seedlings. B. subtilis QST 713 followed by polyoxin $\mathrm{D}$ and $R$. sachalinensis extract followed by B. subtilis QST 713 did not differ from mancozeb.

In general, polyoxin D was the most effective biopesticide against gummy stem blight, which verified the results of the screening experiment. In the sequential experiment, seedlings treated with polyoxin D had less severe disease than seedlings treated with $R$. sachalinensis extract or B. subtilis QST 713 (Table 2). In addition, applying polyoxin $\mathrm{D}$ after $R$. sachalinensis extract or B. subtilis QST 713 improved control compared to $R$. sachalinensis extract or B. subtilis QST 713 used alone. $R$. sachalinensis extract was the least effective of the three biopesticides. Seedlings sprayed with $R$. sachalinensis extract followed by B. subtilis QST 713 (10.4\%) or R. sachalinensis extract followed by polyoxin D $(14.7 \%)$ had less severe gummy stem blight than seedlings treated with only $R$. sachalinensis extract $(32.6 \%)$. Severity on seedlings treated with $R$. sachalinensis extract followed by B. subtilis QST 713 (10.4\%) did not differ from severity on seedlings treated with $B$. subtilis QST 713 (22.6\%).

All combinations of two products were as effective against gummy stem blight as the treatment with three biopesticides (Table 2). In addition, the treatment with three biopesticides was less effective than mancozeb. Therefore, there is no advantage to using $R$. sachalinensis extract, B. subtilis QST 713, and polyoxin $\mathrm{D}$ on the same crop of seedlings.

In only one case was a combination of two biopesticides less effective against gummy stem blight than one of the components. Seedlings treated with $R$. sachalinensis extract followed by polyoxin D had more severe disease (14.7\%) than seedlings treated only with polyoxin D $(2.8 \%)$. This interaction was confirmed in a separate analysis of variance done with the eight combinations involving the three biopesticides, in which there

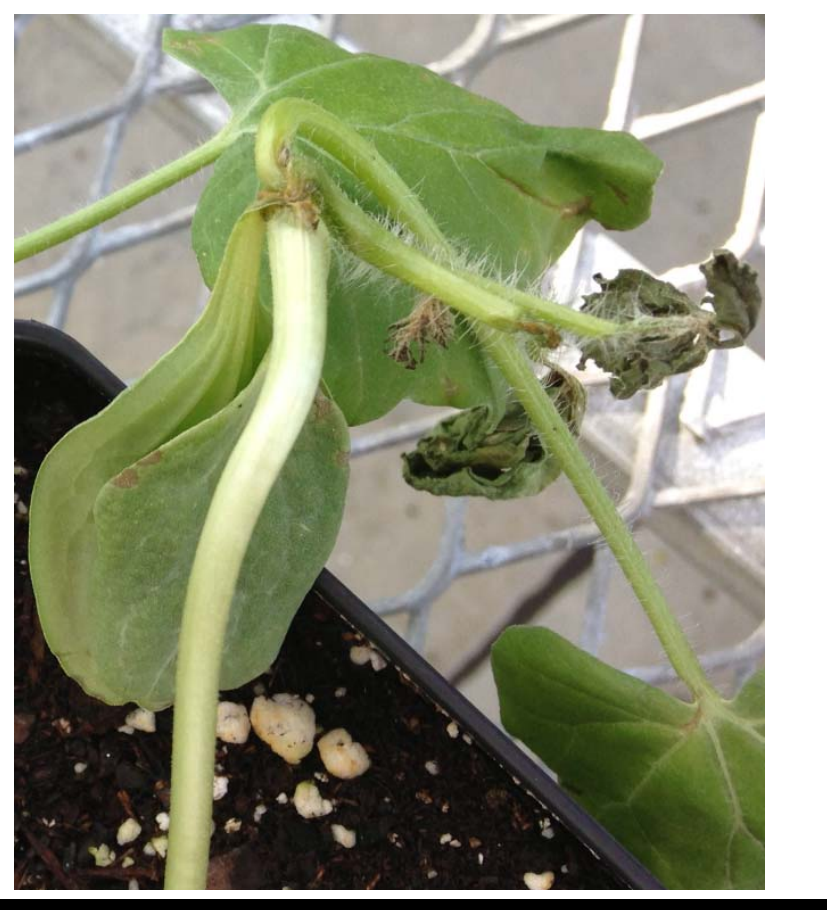

FIGURE 2

Symptoms of anthracnose at the hypocotyl-cotyledon juncture on watermelon seedlings. 
was a significant interaction between treatments that included $R$. sachalinensis extract and polyoxin D $(P=0.0009)$. All other combinations of two or three biopesticides were more effective than, or equivalent to, the components.

In the sequential experiments, water was applied on days when no biopesticide was applied to certain treatments, so that leaves of all seedlings were wet the same number of times. Thus, water was applied twice to seedlings sprayed with $R$. sachalinensis extract and once to seedlings sprayed with B. subtilis QST 713 after treatment, but no water was applied after seedlings were treated with polyoxin $\mathrm{D}$. If water removed some biopesticide residues, then this could be an explanation why $R$. sachalinensis extract and B. subtilis QST 713 were less effective than polyoxin D. The order in which the biopesticides were applied was determined based on their effects on the host plant. $R$. sachalinensis extract, a resistance inducer, was applied first, so there would be a short period after treatment before the seedlings were challenged with the pathogen (Fungicide Resistance Action Committee 2016). $B$. subtilis QST 713 was applied second, because B. subtilis QST 713 produces one or more lipopeptide antibiotics, and other strains of $B$. subtilis have been reported to induce resistance (Fungicide Resistance Action Committee 2016; Joshi and McSpadden Gardener 2006; Kloepper et al. 2004). Polyoxin D was applied last, since it is recommended to be used preventatively (Highland et al. 2014). Further experiments are needed to determine if the application sequence affects the efficacy of biopesticides.

\section{COMBINING BIOPESTICIDES AGAINST ANTHRACNOSE}

The same experimental design was used to screen $R$. sachalinensis extract, B. subtilis QST 713, and polyoxin D at the same rates and in the same sequences against $C$. orbiculare race 2 isolate WMF2 with an inoculation concentration of $10^{5}$ conidia/ml (Keinath 2015). Seedless watermelon 'Tri-X 313' seedlings with two true leaves were sprayed with the same rates of biopesticides at 3,2, and 1 day before inoculation. Seedlings were incubated in a humidity chamber for $24 \mathrm{~h}$ at $100 \%$ relative humidity, returned to the greenhouse, and rated 7 days after inoculation (Keinath 2015). The experiment was done twice. Data were analyzed with SAS PROC MIXED.

B. subtilis QST 713, R. sachalinensis extract, polyoxin D, and all combinations were ineffective against anthracnose on watermelon seedlings. With both incidence (data not shown) and severity ratings (Table 3 ), mancozeb reduced anthracnose in trial one but not in trial two. There was a significant interaction between trial and treatment, because $R$. sachalinensis extract applied alone differed in efficacy between the two trials $(P=$ 0.01 ) (Table 3). Incidence of anthracnose was high, $\geq 65 \%$, in both trials. Approximately $23 \%$ of all seedlings had anthracnose lesions at the base of the hypocotyl or at the point on the hypocotyl where the cotyledons were attached, as observed previously (Fig. 2) (Keinath 2015; Koike et al. 1991; Latin 1993). Between 70 and $50 \%$ of the seedlings with hypocotyl lesions collapsed in trials one and two, respectively. Leaves or cotyledons on $39 \%$ of the remaining seedlings with hypocotyl lesions wilted in the second trial. Wilted portions of seedlings were included in the severity ratings, even if no leaf spots were present. Thus, hypocotyl lesions increased the severity of anthracnose in this experiment. Biopesticides were not effective enough to prevent hypocotyl lesions; mancozeb, with an anthracnose incidence of $98 \%$ in the second trial, also was ineffective. In the field, $B$. subtilis QST 713, R. sachalinensis extract, and polyoxin D were ineffective against anthracnose on watermelon, when biopesticides were applied weekly in the same sequences tested in this experiment (Keinath and DuBose 2014a).

\section{CONCLUSIONS}

Polyoxin D can be used on greenhouse cucurbit seedlings, as it protects against both gummy stem blight and powdery mildew. In Arizona, polyoxin D reduced severity of powdery mildew on muskmelon in the field (Matheron and Porchas 2008). In a previous greenhouse study, B. subtilis QST 713 and $R$. sachalinensis extract were ineffective against powdery mildew on cucurbit seedlings (polyoxin D was not tested) (Keinath and DuBose 2012). However, because polyoxin is not approved by the NOP, it cannot be used in certified organic production. Polyoxin inhibits chitin synthase, the Fungicide Resistance Action Committee Code 19 mode of action class, and is considered to have a medium risk of resistance development (Fungicide Resistance Action Committee 2016; Highland et al. 2014). Therefore, polyoxin D should be applied only once to each planting of cucurbit seedlings in a greenhouse. If additional applications are needed to manage gummy stem blight, mancozeb or cyprodinil-fludioxonil should be used (Keinath 2013b). Because no biopesticides tested in this study controlled anthracnose, mancozeb is likely the best fungicide to use in the greenhouse against this cucurbit seedling disease (Keinath and DuBose 2014b).

\begin{tabular}{|c|c|c|c|c|}
\hline \multicolumn{5}{|c|}{$\begin{array}{c}\text { TABLE } 3 \\
\text { Efficacy of three biopesticides applied alone or in combination against anthracnose on watermelon seedlings. }\end{array}$} \\
\hline Treatment 1 & Treatment 2 & Treatment 3 & \multicolumn{2}{|c|}{ Severity $(\%)^{y}$} \\
\hline Water (inoculated control) & Water & Water & $35.2 \mathrm{ab}$ & $32.1 \mathrm{ab}$ \\
\hline Water & Bacillus subtilis QST713 1.34\% & Water & $30.7 \mathrm{ab}$ & $28.1 \mathrm{ab}$ \\
\hline Reynoutria sachalinensis extract $5 \%$ & Water & Water & $62.0 \mathrm{a}^{\mathrm{z}}$ & $6.1 \mathrm{bc}^{\mathrm{z}}$ \\
\hline Water & Bacillus subtilis QST713 1.34\% & Polyoxin D zinc salt $5 \%$ & $12.4 \mathrm{bc}$ & $18.6 \mathrm{ab}$ \\
\hline Reynoutria sachalinensis extract $5 \%$ & Water & Polyoxin D zinc salt $5 \%$ & $13.6 \mathrm{bc}$ & $36.3 \mathrm{a}$ \\
\hline Reynoutria sachalinensis extract $5 \%$ & Bacillus subtilis QST713 1.34\% & Polyoxin D zinc salt $5 \%$ & $12.9 \mathrm{bc}$ & $27.5 \mathrm{ab}$ \\
\hline Water & Water & Mancozeb $75 \%$ & $0.0 \mathrm{c}$ & $12.2 \mathrm{abc}$ \\
\hline Water (non-inoculated control) & Water & Water & $0.0 \mathrm{c}$ & $0.0 \mathrm{c}$ \\
\hline
\end{tabular}

${ }^{\mathrm{x}}$ Biopesticides were applied at the rates given in Table 1 .

y Means within columns followed by the same letter are not significantly different, Fisher's Protected LSD, $P \leq 0.01$ for trial 1 and $P \leq 0.05$ for trial 2 .

${ }^{\mathrm{z}}$ Treatment means for Reynoutria sachalinensis extract differed between the two trials $(P=0.0113)$. 


\section{ACKNOWLEDGMENTS}

I am grateful for technical assistance from V. B. DuBose and C. D.

Conrad.

This material is based upon work supported, in part, by National Institute of Food and Agriculture/United States Department of Agriculture under project number SC-1700446. Technical Contribution Number 6421, Clemson University Experiment Station.

\section{LITERATURE CITED}

Boughalleb, N., El Mahjoub, M., Abad-Campos, P., Pérez-Sierra, A., GarcíaJiménez, J., and Armengol, J. 2007. First report of gummy stem blight caused by Didymella bryoniae on grafted watermelon in Tunisia. Plant Dis. 91:468.

Brown, M. E., Howard, E. M., and Knight, B. C. 1970. Seed-borne Mycosphaerella melonis on cucumber. Plant Pathol. 19:198.

Cedeño, L., Carrero, C., and Quintero, K. 2000. Gummy stem blight caused by Didymella bryoniae on watermelon transplants in Mérida, Venezuela. Fitopatol. Venezolana 13:26-29. (In Spanish with English abstract).

Crinò, P., Lo Bianco, C., Rouphael, Y., Colla, G., Saccardo, F., and Paratore, A. 2007. Evaluation of rootstock resistance to Fusarium wilt and gummy stem blight and effect on yield and quality of a grafted 'Inodorus' melon. HortScience 42:521-525.

FRAC. 2016. Code List. Fungicide Resistance Action Committee (FRAC), CropLife Int., Brussels, Belgium. http://www.frac.info

Hendricks, K. E., and Roberts, P. D. 2015. Didymella bryoniae isolates from watermelon seedlings in Florida transplant houses and their sensitivity to boscalid. Plant Health Prog. doi:10.1094/PHP-BR-14-0047.

Highland, B., Dimock, M., and Ockey, S. 2014. Foliar use of Oso 5\% SC (polyoxin D zinc salt) from Certis USA in fungicide programs to control diseases of cucurbits in the US. Phytopathology 104(Suppl. 3):S3.51.

Horn, N. L., and Wilson, W. F. 1955. Evidence of seed transmission of the cucumber anthracnose pathogen. (Abstr.) Phytopathology 45:348.

Joshi, R., and McSpadden Gardener, B. B. 2006. Identification and characterization of novel genetic markers associated with biological control activities in Bacillus subtilis. Phytopathology 96:145-154.

Keinath, A. P. 1996. Spread of Didymella bryoniae from contaminated watermelon seed and transplants in greenhouse and field environments. Pages 65-72 in: Recent Research Developments in Plant Pathology, Vol. 1. S. G. Pandalai, ed. Research Signpost, Trivandrum, India.

Keinath, A. P. 2009. Sensitivity to azoxystrobin in Didymella bryoniae isolates collected before and after field use of strobilurin fungicides. Pest Manag. Sci. 65:1090-1096.

Keinath, A. 2011. From native plants in Central Europe to cultivated crops worldwide: The emergence of Didymella bryoniae as a cucurbit pathogen. HortScience 46:532-535.

Keinath, A. P. 2012. Differential sensitivity to boscalid in conidia and ascospores of Didymella bryoniae and frequency of boscalid-insensitive isolates in South Carolina. Plant Dis. 96:228-234.

Keinath, A. P. 2013. Diagnostic guide for gummy stem blight and black rot on cucurbits. Plant Health Prog. doi:10.1094/PHP-2013-1024-01-DG.

Keinath, A. P. 2013. Susceptibility of cucurbit rootstocks to Didymella bryoniae and control of gummy stem blight on grafted watermelon seedlings with fungicides. Plant Dis. 97:1018-1024.

Keinath, A. P. 2015. Identification of races of Colletotrichum orbiculare on muskmelon in South Carolina. Plant Health Prog. doi:10.1094/PHP-BR15-0004.
Keinath, A. P., and DuBose, V. B. 2012. Controlling powdery mildew on cucurbit rootstock seedlings in the greenhouse with fungicides and biofungicides. Crop Prot. 42:338-344.

Keinath, A. P., and DuBose, V. B. 2014. Evaluation of biological and conventional fungicides to control anthracnose on watermelon, 2013. Plant Dis. Manage. Rep. 8:V218. doi: 10.1094/PDMR08.

Keinath, A. P., and DuBose, V. B. 2014. Evaluation of fungicides rotated with mancozeb to control anthracnose on watermelon, 2013. Plant Dis. Manage. Rep. 8:V220. doi:10.1094/PDMR08.

Keinath, A. P., May, W. H. III., and DuBose, V. B. 2000. Effect of sequential or alternating applications of Quadris and companion fungicides on watermelon foliar diseases. Fungic. Nematic. Tests 55:290.

Kloepper, J. W., Ryu, C.-M., and Zhang, S. 2004. Induced systemic resistance and promotion of plant growth by Bacillus spp. Phytopathology 94:12591266.

Koike, S. T. 1997. First report of gummy stem blight, caused by Didymella bryoniae, on watermelon transplants in California. Plant Dis. 81:1331.

Koike, S. T., Tidwell, T. E., Fogle, D. G., and Patterson, C. L. 1991. Anthracnose of greenhouse-grown watermelon transplants caused by Colletotrichum orbiculare in California. Plant Dis. 75:644.

Latin, R. 1993. Diseases and pests of muskmelons and watermelons. Coop. Ext. Pub. No. BP-44. Purdue Univ., West Lafayette, IN. https://www.extension.purdue.edu/extmedia/bp/bp-44.html

Leahy, J., Mendelsoh, M., Kough, J., Jones, R., and Berckes, N. 2014. Biopesticide oversight and registration at the U.S. Environmental Protection Agency. Pages 3-18 in: Biopesticides: State of the Art and Future Opportunities. A. D. Gross, J. R. Coats, S. O. Duke, and J. N. Seiber, eds. American Chemical Soc., Washington, DC.

Lee, D.-H., Mathur, S. B., and Neergaard, P. 1984. Detection and location of seed-borne inoculum of Didymella bryoniae and its transmission in seedlings of cucumber and pumpkin. Phytopathol. Z. 109:301-308.

Matheron, M. E., and Porchas, M. 2008. Comparison of fungicides for management of powdery mildew on muskmelon, 2007. Plant Dis. Manage. Rep. 2:V085. doi:10.1094/PDMR02.

McGovern, R. J. 1993. Evaluation of fungicides and bicarbonates for control of downy mildew and gummy stem blight on cantaloupe, 1992. Fungic. Nematic. Tests 48:107.

Rankin, H. W. 1954. Effectiveness of seed treatment for controlling anthracnose and gummy stem blight of watermelon. Phytopathology 44:675-680.

Stewart, J. E., Turner, A. N., and Brewer, M. T. 2015. Evolutionary history and variation in host range of three Stagonosporopsis species causing gummy stem blight of cucurbits. Fungal Biol. 119:370-382.

Stevenson, K. L., Langston, D. B., Jr., and Seebold, K. W. 2004. Resistance to azoxystrobin in the gummy stem blight pathogen documented in Georgia. Plant Health Prog. doi:10.1094/PHP-2004-1207-01-RS.

USDA. 2006. United States standards for grades of watermelon. United States Dept. of Agric. (USDA), Washington, DC https://www.federalregister.gov/articles/2006/02/21/E6-2385/unitedstates-standards-for-grades-of-watermelons

van Steekelenburg, N. A. M. 1983. Epidemiological aspects of Didymella bryoniae, the cause of stem and fruit rot of cucumber. Neth. J. Plant Pathol. 89:75-86.

Wasilwa, L. A., Correll, J. C., and Morelock, T. E. 1996. Further characterization of Colletotrichum orbiculare for vegetative compatibility and virulence. (Abstr.) Phytopathology 86:S62.

Ziv, O., and Zitter, T. A. 1992. Effects of bicarbonates and film-forming polymers on cucurbit foliar diseases. Plant Dis. 76:513-517. 